Teologia i Moralność, volumen 12(2017), numer 1(21)

doi: 10.14746/tim.2017.21.1.5

JÓZEF WRÓBEL

Katolicki Uniwersytet Lubelski Jana Pawła II

Wydział Teologii

\title{
Stanowisko episkopatów Niemiec i Polski wobec masowego napływu migrantów ${ }^{1}$
}

W przeszłości Europa była już nieraz przestrzenią wędrówki ludów. Aktualnie proces ten osiągnął nieznane dotychczas rozmiary. Ponad milion migrantów z Bliskiego Wschodu i z Afryki stanęło u jej bram. Mieszkańcy regionów gospodarczo zaniedbanych szukają tutaj lepszego życia jako emigranci. Z kolei przybysze z regionów ogarniętych wojną oczekują bezpieczniejszego, godniejszego i wolnego od strachu życia jako uchodźcy.

$\mathrm{Z}$ napływem obcokrajowców nie mogą sobie poradzić rządy państw, nawet ich oczekujących, oraz organizacje międzynarodowe. Sprzeciw wobec proponowanych rozwiązań migracyjnych wyraża wielu obywateli państw będących celem tych wędrówek. Ich obawy budzi napływ kulturowo obcych mas, ich słaba integracja ze społeczeństwami europejskimi w zakresie kultury, etosu pracy, demokracji i tolerancji religijnej. Niechęć budzi dodatkowo strach przed zamachami terrorystycznymi czy też przed ulicznymi burdami, jak to miało miejsce w Kolonii w Sylwestra 2015 roku. Wielu Europejczyków nie życzy sobie też ciągłych niepokojów, jakie są wynikiem napadów na imigrantów przez skrajnie prawicowe ugrupowania.

Wobec powyższych problemów nie mogą przejść obojętnie lokalne wspólnoty chrześcijańskie. Starają się one wypracować odpowiedź, jaką dyktuje Ewangelia i wrażliwość papieża Franciszka. Z drugiej strony nie jest im też obojętna odpowiedzialność za państwo i harmonijną egzystencję jego obywateli. W efekcie problem imigracji stał się poważnym wyzwaniem dla episkopatów różnych krajów, w tym Niemiec i Polski. Odpowiedź tych dwóch

${ }^{1}$ Niniejsza publikacja jest oparta na referacie wygłoszonym na dorocznym zjeździe Stowarzyszenia Teologów Moralistów Polskich w Zakopanem, 14.06.2016. 
Kościołów lokalnych jest przedmiotem niniejszych analiz, m.in. dlatego, że niekiedy wydaje się ona różna.

\section{Kościół niemiecki}

W Kościele niemieckim sprawami migrantów, azylantów i Romów zajmuje się Komisja do spraw Migracji (Migrationskommission). Jej aktualnym przewodniczącym jest ordynariusz diecezji Hildesheim, biskup Norbert Trelle. Zainteresowanie niemieckich biskupów problemem migracji ma dłuższą historię, gdyż kraj ten stał się celem wędrówek obcokrajowców, począwszy od początku lat sześćdziesiątych XX wieku, kiedy Niemcy szybko odbudowały swoją gospodarkę zniszczoną przez II wojnę światową, stworzyły liczne miejsca pracy oraz otwarły granice dla tak zwanych gastarbeiterów. Tylko w 1961 roku w Niemczech znalazło pracę ponad 580 tys. Włochów. Mniej więcej w tym samym czasie przybyła do Niemiec duża grupa Turków i obywateli byłej Jugosławii. Kolejny napływ obcokrajowców do Niemiec miał miejsce w latach dziewięćdziesiątych. Tym razem byli to migranci z krajów Unii Europejskiej $^{2}$, z Bliskiego Wschodu i z Afryki. Według oficjalnych statystyk w 1990 roku w Niemczech żyło 5 mln 342 tys. obcokrajowców, a w 2015 roku 9 mln 108 tys. W tym samym roku (2015) największą grupę migrantów stanowili Turcy ( $1 \mathrm{mln} 506$ tys.). Jednak ich liczba w stosunku do poprzedniego roku (2014) zmniejszyła się o 21 tys. osób. Na drugim miejscu są Polacy (741tys.), przy czym ich liczba zwiększyła się o 67 tys. Trzecie miejsce zajmują Włosi (596 tys.) ze wzrostem o 21,6 tys., na kolejnych znajdują się: Rumunii, Syryjczycy, Grecy, Chorwaci, Rosjanie, Serbowie, Bułgarzy ${ }^{3}$.

Niemcy stały się więc kolejny raz celem masowego napływu migrantów w latach 2015-2016. Zgodnie z powszechną opinią motorem nowej fali migracyjnej stały się zachęty urzędu kanclerskiego tego kraju oraz niektórych polityków Unii Europejskiej. Proponowali oni mieszkańcom regionów objętych wojnami i niedorozwojem osiedlenie się w krajach Unii Europejskiej. Wśród tych polityków znaczącą rolę odgrywał m.in. przewodniczący Komisji do

2 Są to osoby pochodzące z: Belgii, Danii, Estonii, Finlandii, Francji, Irlandii, Łotwy, Litwy, Luksemburga, Malty, Holandii, Austrii, Polski, Szwecji, Słowacji, Słowenii, Czech, Węgier, Wielkiej Brytanii, Cypru.

${ }^{3}$ Por. F. Woellert, S. Kröhnert, L. Sippel, R. Klingholz, Ungenutzte Potenziale. Zur Lage der Integration in Deutschland, Berlin 2009, s. 12-27; „Portal Berlin-Institut für Bevölkerung und Entwicklung", http://www.berlin-institut.org/fileadmin/user_upload/Zuwanderung/Integration_ RZ_online.pdf [dostęp: 29.12.2016]; por. także Anzahl der Ausländer in Deutschland nach Herkunftsland in den Jahren 2014 und 2015. „Portal Statista - Das Statistik-Portal”, http://de.statista. $\mathrm{com} / \mathrm{statistik} /$ daten/studie/1221/umfrage/anzahl-der-auslaender-in-deutschland-nach-herkunftsland/ [dostęp: 30.05.2016]. 
spraw Migracji Niemiec, który wzywał kraje Unii do wychodzenia naprzeciw migrantom docierającym do granic Europy ${ }^{4}$.

Postawę wspomnianych polityków krytykował, m.in., czeski kardynał, Dominik Duka OP ${ }^{5}$. Niejednolite są także wypowiedzi na ten temat episkopatu Niemiec. $Z$ jednej strony biskupi niemieccy jednoznacznie opowiadają się za przyjmowaniem uchodźców, powołując się na ideał ewangeliczny i humanitarny. $Z$ drugiej strony nie brak też głosów pragmatycznie oceniających zaistniałą sytuację i wzywających do rozsądku, w tym m.in. przewodniczącego Konferencji Episkopatu Niemiec, kard. Reinharda Marxa.

Istotne znaczenie dla pozytywnej oceny migracji przez biskupów niemieckich ma świadomość, że społeczeństwo niemieckie jest „częścią globalnej wspólnoty losu" (Teil einer globalen Schicksalsgemeinschaft). Ważne są dla nich wezwania papieża Franciszka podkreślającego ,globalizację miłości bliźniego" (Globalisierung der Nächstenliebe), która powinna być chrześcijańską odpowiedzią na „globalizację obojętności” (Globalisierung der Gleichgültigkeit $)^{6}$. Postawę tę papież Franciszek piętnował już w czasie wizyty w Parlamencie Europejskim, gdzie mówił o

skłonności do roszczenia sobie przez społeczeństwo europejskie coraz większych praw indywidualistycznych. Tendencja ta skrywa koncepcję osoby ludzkiej oderwanej od wszelkiego kontekstu społecznego i antropologicznego, niemal jako „monady”, coraz bardziej nieczułej na inne otaczające ją ,monady”, a w efekcie o „ogólnym wrażeniu zmęczenia i starzenia się Europy - przypominającej staruszkę, już bezpłodną i nie tętniącą życiem ${ }^{7}$.

Postawie ewangelicznej papież Franciszek nadał konkrety wyraz, kiedy 8 lipca 2013 roku odwiedził wyspę uchodźców Lampedusę i gdzie użył podjętych przez biskupów niemieckich słów o „globalizacji obojętności”8.

Konferencja Episkopatu Niemieckiego zajęła się problemem migracji na zebraniu plenarnym, które miało miejsce 15-18 lutego 2016 roku w klasztorze

${ }^{4}$ Por. Deutsche Bischofskonferenz, Pressemitteilung, Die Alternative zur Rettung ist der Tod. 27.10.2014, „Portal Bistum Erfurt”, http://www.bistum-erfurt.de/aktuelles/archiv-2014/bischoftrelle-zur-seenotrettung-von-fluechtlingen.html [dostęp: 27.05.2016].

5 Por. A. Grajewski, My mieliśmy racje, „Gość Niedzielny” 93(2016) nr 20 (15.05.2016), s. 11.

${ }^{6}$ Por. Deutsche Bischofskonferenz, Flüchtlingshilfe der katholischen Kirche, „Portal Deutsche Bischofskonferenz", http://www.dbk.de/fluechtlingshilfe/home/ [dostęp: 12.05.2016; 04.01.2017].

${ }^{7}$ Address of the Holy Father. Visit at the European Parliament. Strasbourg 25.11.2014, "Portal Jezuici.pl", http://jezuici.pl/wp-content/uploads/2014/11/Franciszek-przemowienie-w-ParlamencieEuropejskim.pdf [dostęp: 12.05.2016].

8 Por. Franciszek. Homily. Visit to Lampedusa. 8 July 2013, "Portal Vatikan.va", http://w2.vati can.va/content/francesco/it/homilies/2013/documents/papa-francesco_20130708_omelia-lampedu sa.html [dostęp: 12.05.2016]. 
pocysterskim Schöntal należącym do diecezji Rottenburg-Stuttgart. Do zagadnienia tego nawiązał już na wstępie nuncjusz apostolski w Niemczech, abp Nikola Eterović. Wyraził on szacunek dla zatroskania biskupów niemieckich, tak katolickich, jak i ewangelickich, o los uchodźców. Postawę ich zaliczył do dzieł miłości bliźniego i uczynków miłosierdzia wobec ducha i ciała. Szczególnym znakiem tej troski jest to, że w 2015 roku niemieccy biskupi mieli poważny wkład w przyjęcie i wsparcie więcej niż 1,1 miliona uchodźców pochodzących z obszarów ubóstwa i toczących się wojen.

Środa, 17 lutego 2016 roku, była w całości poświęcona studium problemów migracyjnych (temat dnia: „Kultura przyjęcia i solidarności - uchodźcy i migranci jako wyzwanie"). W dyskusję nad poszczególnymi zagadnieniami wprowadzały prezentacje specjalistów. Stwierdzili oni, m.in., że w wymiarach ogólnoświatowych liczba uchodźców nie zwiększyła się znacząco w ostatnim czasie. Natomiast w kontekście kryzysu na Bliskim Wschodzie Niemcy stały się celem ruchów migracyjnych ze względu na ich polityczną i gospodarczą stabilność oraz załamanie się w Europie otwarcia na uchodźców i migrantów. Niemieccy biskupi wyrazili dalej opinię, że mimo politycznych kontrowersji rozwiązanie konkretnych problemów musi być też pierwszorzędnym celem działań rządu. Szczególnym przedmiotem jego troski winny być przypadki rasizmu i agresji przeciw uchodźcom. Znaczące było wystąpienie o. Manfreda Kolliga SSCC, szefa wydziału duszpasterskiego diecezji Münster. Podkreślił on, że uchodźcy przybywający do Niemiec nie mogą być traktowani jako „problem”, ale jako „orędzie Boga” (Botschaft Gottes). Kościół musi dostrzec w nich znak czasu. W czasie wystąpień i dyskusji nie zabrakło też teologicznie umotywowanych pytań o możliwość przekazywania migrantom wiary (,Jaką wiarę przekażemy migrantom?").

Owocem powyższego Zebrania Plenarnego Konferencji Episkopatu Niemiec było wydanie specjalnego dokumentu poświęconego migracji pod tytułem Wyznaczniki eklezjalnego zaangażowania na rzecz uchodźców (Leitsätze des kirchlichen Engagements für Flüchtlinge) ${ }^{9}$. Pierwsza część tego dokumentu to syntetyczna analiza aktualnej sytuacji w zakresie migracji. Część druga jest poświęcona omówieniu kościelnego zaangażowania na rzecz migrantów.

Dla biskupów niemieckich powinność troski o uchodźców i migrantów na miarę ich osobowej godności jest w całej pełni oczywista. W tym zaangażowaniu ujawnia się bowiem tożsamość Kościoła. Pomoc instytucji kościelnych uchodźcom realizuje się na wszystkich płaszczyznach właściwej im aktywności w duchu zasady pomocniczości. W pomoc tę włączają się kompetentnie osoby

9 Por. Deutsche Bischofkonferenz, Leitsätze des kirchlichen Engagements für Flüchtlinge. Kloster Schöntal. 18. Februar 2016, „Portal Deutsche Bischofskonferenz”, http://www.dbk. de/fileadmin/redaktion/diverse_downloads/presse_2016/2016-031-Anlage-1-Leitsaetze-FVVPressebericht.pdf [dostęp: 29.12.2016]. 
reprezentujące 27 diecezji niemieckiego Kościoła, wspólnot zakonnych, Caritas i innych organizacji eklezjalnych. Oto główne wyznaczniki tej postawy:

- Kościół angażujący się na rzecz uchodźców koncentruje w szczególny sposób swoją uwagę na spotkaniu z drugim człowiekiem i towarzyszeniu mu, niezależnie od jego pochodzenia, społecznego statusu, wyznawanej religii, światopoglądu, płci i płciowej orientacji.

- Kościół niemiecki pragnie być adwokatem wszystkich pokrzywdzonych ludzi, zwłaszcza tych, którzy zostają zepchnięci na margines społeczny, nie mogą żyć z własnej pensji, renty czy też zasiłku dla bezrobotnych, we własnym mieszkaniu, szukają wykształcenia i pracy.

- Kościół poczuwa się do szczególnej odpowiedzialności za społeczną integrację ludzi wywodzących się z innej kultury i religii. Niemniej jednak Kościół zdaje sobie też sprawę z tego, że uchodźcy przybywający do Niemiec pragną jedynie żyć w pokoju i sprawiedliwości do czasu, aż będą mogli wrócić do swojej ojczyzny. Powrót ten nie wydaje się bliski. Stąd Republika Federalna Niemiec staje się dla nich nową ojczyzną. Oznacza to, że ludziom tym trzeba umożliwić opanowanie języka, kontynuowanie nauki i studiów, zapewnić szansę ,zdobywania zawodu odpowiednio do zapotrzebowania niemieckiego rynku pracy".

Trzecia część dokumentu jest poświęcona płaszczyznom zaangażowania Kościoła niemieckiego na rzecz migrantów. To wierni nadają konkretny kształt tej pomocy. Dzięki nim azylanci odnajdują się w nowej rzeczywistości. Ważną rolę w tym procesie odgrywa praca duszpasterska, zwłaszcza z uchodźcami wyznań chrześcijańskich. Tworzy ona przestrzeń, w której obcokrajowcy łatwo się odnajdują. Jedną z form pomocy jest udostępnianie uchodźcom mieszkań w kościelnych budynkach. Dzięki temu zostaje wyeliminowane niebezpieczeństwo powstawania gett. Osiągnięcie tych celów ułatwia również włączenie się uchodźców w życie społeczne dzięki możliwości pracy, kształcenia, zdobywania zawodu, tworzeniu przedszkoli, szkół, niższego i wyższego stopnia, w tym także dla dorosłych; w dalszej perspektywie także dzięki dostępowi do opieki zdrowotnej w wymiarze fizycznym i psychicznym.

Prowadzone w czasie zebrania biskupów dyskusje oraz treść powyższego dokumentu przedstawił na konferencji prasowej przewodniczący Konferencji Episkopatu Niemieckiego, kardynał Reinhard Marx, ordynariusz archidiecezji monachijskiej. Zamknął on je w trzech głównych wyznacznikach kościelnej postawy wobec uchodźców:

W empatii: Kościół i wierni nie mogą pozostać obojętni na cierpienia uchodźców. Nie wystarczy aktywność społeczna. Potrzebna jest również gotowość do spotkania Chrystusa w cierpiących bliźnich.

W rzeczowości (Sachlichkeit): W aktualnej dyskusji Kościół opowiada się za skonkretyzowanym podejściem do problemu migracji, czyli za prak- 
tycznymi rozwiązaniami problemów oraz za społecznym konsensusem na rzecz ich przyjęcia. Jednocześnie opowiada się on przeciwko panującej w niektórych kręgach histerii i rozpowszechnianiu dezorientujących opinii (vagabundierende Stimmungen).

W praktyce: Kościelne zaangażowanie na rzecz uchodźców wyraża się w gotowości do uczestnictwa, kreatywności i wyobraźni uczestniczących. W takiej postawie solidarności urzeczywistnia się duchowy fundament i samoświadomość służebności Kościoła.

Problem migracji był też tematem specjalnego spotkania przedstawicieli Kościołów i władz Niemiec. Miało ono miejsce 11 marca 2016 roku w Norymberdze. W rozmowach uczestniczyli: prezydent Urzędu do spraw Migracji i Uchodźców F.J. Weise, wiceprezydent tegoż urzędu, Michael Griesbeck, biskup Kościoła Ewangelicko-Luterańskiego, prof. dr Heinrich Bedford-Strohm oraz arcybiskup Hamburga, dr Stefan Heße. W czasie posiedzenia przedstawiciele władz Republiki Federalnej Niemiec poinformowali przedstawicieli obydwu Kościołów o zastosowanych przez państwo środkach, które mają przyśpieszyć działania służące uchodźcom. Strony reprezentowały zgodne stanowisko, że każda prośba o azyl musi być sprawnie rozpatrzona. Przedstawiciele Kościołów zwrócili przy tym uwagę na to, że to przyśpieszenie musi iść jednak w parze z poszanowaniem praworządności. Arcybiskup Hesse stwierdził ponadto, że „każdy wnioskodawca o przyznanie mu azylu ma prawo do indywidualnego, uczciwego, obiektywnego [tzn. wolnego od uprzedzeń] postępowania”, zaś „,przyśpieszonej procedurze winno towarzyszyć prawne poradnictwo". Z kolei ewangelicko-luterański biskup podkreślił, że ,potrzeby uchodźców wymagających szczególnej opieki, jak na przykład samotnie podróżujących kobiet, młodocianych bez opieki, czy osób z problemami psychicznymi, winny być uwzględnione w każdym przypadku".

W czasie rozmów zwrócono również uwagę na niedomagania prawne. Dotyczy to szczególnie ograniczeń stworzonych przez prawo azylowe, które nie pozwalało na łączenie się rodzin uciekinierów z Syrii. Członkowie spotkania uznali, że bariery te stoją w oczywistej sprzeczności z prawami osobowymi migrantów i z troską o ich dobro. Przedstawiciele Kościołów odnieśli się też krytycznie do ograniczeń w przyznawaniu azylu w przypadku chorych uchodźców. Przedstawiciele urzędu zajmującego się uchodźcami zapewniali, że państwo niemieckie nie wykluczy nikogo, kto będzie się znajdował w trudnej sytuacji zdrowotnej. Arcybiskup Heße zauważył, że osobom chorym powinna być zagwarantowana właściwa opieka medyczna już w ich kraju ${ }^{10}$.

${ }^{10}$ Por. Jeder Asylsuchende hat Anspruch auf ein individuelles, faires und unvoreingenommenes Verfahren. Spitzentreffen zwischen den Kirchen und dem Bundesamt für Migration und Flüchtlinge. Nürnberg 11.03.2016, „Portal Deutsche Bischofskonferenz”, http://www.dbk.de/presse/details/?suc 
Z kolei 2-4 marca 2016 roku miała miejsce w Berlinie XII Doroczna Konferencja na temat „Nielegalności” (XII. Jahrestagung Illegalität). Konferencja ta odbyła się z inicjatywy Katolickiego Forum „Życie w Nielegalności”"11, Katolickiej Akademii w Berlinie oraz Rady do spraw Migracji ${ }^{12}$. Tytuł spotkania brzmiał „Ludzie bez dokumentów w cieniu nowej debaty na temat integracji”. W konferencji wzięło udział 120 przedstawicieli niemieckiego Kościoła katolickiego, organizacji pozarządowych, administracji, polityki i gospodarki. Analizowali oni problemy migrantów bez dokumentów osobistych. We wprowadzającym wystąpieniu biskup Norbert Trelle, przewodniczący Komisji Episkopatu Niemiec do spraw Migracji i Katolickiego Forum ,Życie w Nielegalności”, przypomniał, że „każdy człowiek - niezależnie od jego statusu prawnego - ma niezaprzeczalny tytuł do poszanowania jego fundamentalnych praw”. W praktyce oznacza to, że również uciekinierzy żyjący w Niemczech nielegalnie winni mieć prawo do edukacji czy też do opieki medycznej.

Mając na uwadze aktualne problemy związane z migracją, biskup N. Trelle wskazał też na trzy nowe wyzwania. Po pierwsze, należy się obawiać, że zastrzeżenia do migrantów niemających prawa do pobytu w Niemczech będą wzrastać. W tym kontekście konieczne jest zwrócenie uwagi na wyważony i pełny szacunku stosunek do migrantów w publicznych dyskusjach. Po drugie, powinno się zwracać uwagę na to, aby w kontekście aktualnych nastrojów społecznych nie utrudniać prób zalegalizowania pobytu lub wprost go nie uniemożliwiać. Po trzecie, należy się liczyć z tym, że polityczne i administracyjne zaostrzenie wymagań azylowych będzie prowadzić do wzrostu liczby osób nielegalnie przebywających w Niemczech. W końcu wszystkie strony uczestniczące w konferencji opowiedziały się za poszanowaniem osobowej godności każdego człowieka chcącego uregulować swój pobyt w Niemczech.

W dalszych wykładach i w czasie dyskusji stanowisko przedstawicieli Kościoła podzielali w większości przedstawiciele struktur państwowych i społecznych. Pewien wyjątek stanowiła opinia Thorstena Klutego, sekretarza stanu w Ministerstwie Pracy, Integracji i Kwestii Społecznych Landu Nordhein-Westfalen. Wprawdzie opowiedział się on za tym, aby w Niemczech, podobnie jak we Francji i w Stanach Zjednoczonych, niektórzy ludzie bez dokumentów mogli uregulować swój pobyt, ale jednocześnie zaznaczył, że

hbegriff $=$ migration $\&$ presseid $=3074 \& c H a s h=d 9 c 5 b 52 \mathrm{e} 81 \mathrm{fbcfc} 3040 \mathrm{e} 74390 \mathrm{~b} 323 \mathrm{f} 32$ [dostęp: 14.05 . 2016].

11 „Katolickie Forum «Życie w Nielegalności»” zostało założone w 2004 roku z inicjatywy Komisji Konferencji Episkopatu Niemiec do spraw Migracji. Aktualnym przewodniczącym tej Komisji oraz Forum jest biskup Norbert Trelle.

12 Powyższą Radę tworzy niezależne stowarzyszenie naukowców specjalizujących się w kwestiach migracji. 
rozwiązanie to $\mathrm{w}$ aktualnej sytuacji politycznej ma nikłe szanse na realizację. Podobne stanowisko reprezentował rzecznik CDU/CSU, Stephan Mayer ${ }^{13}$.

Problem migracji nie mógł zostać pominięty na najważniejszym wydarzeniu Kościoła katolickiego w Niemczech, a mianowicie na trwającym pięć dni „Dniu katolików” (Katolikentag). W tym roku (2016) był on obchodzony w Lipsku. W homilii wygłoszonej w czasie Mszy Świętej zamykającej uroczystości przewodniczący Konferencji Episkopatu Niemiec, kardynał Reinhard Marx, stwierdził, że „każdy uchodźca powinien być traktowany z godnością [...]. Istnieją zasady wynikające $\mathrm{z}$ Ewangelii, których nie wolno naruszać: uchodźca, który dotrze do naszych granic, powinien być potraktowany godnie, powinien być objęty uczciwym postępowaniem [azylowym] i nie można go odsyłać tam, gdzie toczy się wojna i grożą mu prześladowania"14. Jednocześnie podkreślił: „Także jako Kościół mówimy - trzeba ograniczyć liczbę uchodźców”. Niemcy „nie są w stanie przyjąć wszystkich cierpiących z całego świata. [...] Trzeba mieć na względzie nie tylko miłosierdzie, ale i rozsądek". W tej samej wypowiedzi wyraził on swój szacunek i wsparcie dla kanclerz Angeli Merkel oraz dla prowadzonej przez nią polityki ${ }^{15}$.

Biskupi niemieccy podjęli też konkretne kroki mające na celu pomoc uchodźcom. W trosce o warunki życia chrześcijańskich uchodźców Konferencja Episkopatu Niemiec przeprowadza wizje lokalne i sondaże w miejscach ich przebywania, zwracając uwagę na jakość zaangażowania kościelnych, państwowych i prywatnych organizacji charytatywnych, jak Caritas czy zakon maltański. Przedmiotem szczególnej uwagi były rzadkie, ale jednak pojawiające się przypadki zastraszania i dyskryminacji uchodźców, a nawet przemocy wobec nich. Konsekwentnie uznano za konieczne wprowadzenie dla nich stosownych środków ochrony. Wypracowywane zaś przez niemieckich biskupów standardy w tej materii winny służyć budowaniu poczucia wspólnoty między osobami należącymi do różnych wyznań, religii i kultur ${ }^{16}$.

${ }^{13}$ Por. XII. Jahrestagung Illegalität in Berlin beendet. Die Wahrung der Menschenwürde ist kein Luxusgut, sondern Ausgangs- und Zielpunkt unserer rechtsstaatlichen Ordnung, „Portal Deutsche Bischofskonferenz", http://www.dbk.de/presse/details/?suchbegriff=migration\&presseid= 3064\&cHash=fbdeec6a0eea5f101609c06a13afc301 [dostęp: 15.05.2016].

${ }^{14}$ Por. R. Marx. Nie wolno odsyłać uchodźców, „Portal Interia.pl”, http://fakty.interia. $\mathrm{pl} /$ raporty/raport-imigranci-z-afryki/informacje/news-kardynal-marx-nie-wolno-odsylacuchodzcow,nId,2209926\#utm_source=paste\&utm_medium=paste\&utm_campaign=firefox [dostęp: 30.05.2016].

15 Por. Warum nun auch Kardinal Marx eine Begrenzung der Migration fordert. Bonn. 07.02.2016, „Portal: CNA. Deutsche Ausgabe”, http://de.catholicnewsagency.com/story/kardinamarx-fordert-nun-begrenzung-der-migration-0468 [dostęp: 11.06.2016].

16 Por. Situation in Flüchtlingseinrichtungen. Umfrage in den deutschen Bistümern. 10.05.2016, „Portal Deutsche Bischofskonferenz”, http://www.dbk.de/presse/details/?presseid=3110\&cHash=90 3aeb812de6800aa679d8cb3d42cadd [dostęp: 12.05.2015]. 
Konkretne działania podjęły też poszczególne diecezje we właściwych im okręgach jurysdykcyjnych. Omówimy kilka przykładów.

Trzeba odnotować, że strona internetowa archidiecezji monachijskiej, w przeciwieństwie do innych diecezji, nie ma w głównym menu rzucającego się w oczy linku do tematyki uchodźców. Dopiero po głębszej penetracji strony (wiosną 2016 roku; jesienią tegoż roku strona ta została zmieniona i nie jest już tak wyrazista ${ }^{17}$ ) można było znaleźć dział zatytułowany „Emigracja, azyl i integracja" (Flucht, Asyl und Integration). Były tam przedstawione dane z kwietnia 2016 roku na temat pomocy udzielanej uchodźcom. Z opisu przedstawionych działań można się było dowiedzieć m.in., że archidiecezja przygotowała 82 obiekty przeznaczone do zakwaterowania 1453 uchodźców. Caritas diecezji prowadzi także biura pomocy i porad dla uchodźców oraz ubiegających się o azyl. Jednocześnie gwarantuje rozlokowanie i opiekę małoletnim uchodźcom. Według tych danych Caritas objął opieką około 850 młodych ludzi, którzy przybyli do Niemiec bez rodzin. Opieka nad uchodźcami i azylantami obejmuje także: (1) możliwość kształcenia się i zdobycie zawodu, (2) społeczną integrację poprzez aktywność w parafiach, które przyjmą uchodźców, (3) pracę koordynatorów i pomocników, których zadaniem jest wspieranie azylantów w ich włączeniu się w życie lokalnych społeczności.

Archidiecezja berlińska ma na swoim portalu stronę internetową pod tytułem „Pomoc dla uchodźców w archidiecezji Berlin” (Hilfe für Flüchtlinge im Erzbistum Berlin). Proponuje na niej różne formy pomocy. Przygotowała kwatery dla 100 osób, a Caritas archidiecezji dla dalszych 200 osób. Ponadto archidiecezja stworzyła specjalny fundusz dla polepszenia warunków życia uchodźców w wysokości po 250 tys. euro na rok 2015 i 2016, czyli razem 500 tys. euro ${ }^{18}$.

Diecezja Hildesheim razem z lokalnym Kościołem Ewangelicko-Augsburskim wydała modlitewnik pod tytułem Du bist der Gott meiner Stärke (Ps 43,2; „Ty jesteś Bogiem mojej siły [mocy]”; w Biblii Tysiąclecia: „Ty jesteś Bogiem mojej ucieczki”). Zamieszczone są w nim teksty biblijne i modlitwy w pięciu językach: niemieckim, angielskim, francuskim, arabskim i tigrinya (Erytrea). Modlitewnik zawiera też adresy prawosławnych parafii na terenie tej diecezji. Nakład wynosi 8 tys. egzemplarzy, przygotowywane jest wznowienie ${ }^{19}$.

${ }^{17}$ Dział dotyczący migrantów znalazł się pod zakładką „Dorośli” („Erwachsene”), i dalej pod okienkiem „Mapa solidarności. Chrześcijanie pomagają uciekinierom” („Landkarte der Solidarität. Christen helfen Flüchtlingen") omówine zostają formy pomocy migrantom (por. https://www. erzbistum-muenchen.de/Dioezesanrat/Page063617.aspx. [dostęp: 28.12.2016]).

18 Por. Erzbistum Berlin, Hilfe für Flüchtlinge im Erzbistum Berlin, „Portal Erzbistum Berlin”, http://www.erzbistumberlin.de/hilfe/fluechtlinge-im-erzbistum-berlin/ [dostęp: 01.06.2016].

19 Por. Fünf Sprachen in einem Gebetbuch. Kirchen geben Andachtsbuch für christliche Flüchtlinge heraus, „Portal Bistum Hildesheim”, https://www.bistum-hildesheim.de/bistum/nachrichten/artikel/news-title/fuenf-sprachen-in-einem-gebetbuch-6585/ [dostęp: 01.06.2016]. 


\section{Kościół polski}

W nowszej historii państwo polskie nie doświadczyło masowego napływu migrantów czy uchodźców. W bardzo ograniczonym zakresie miał on miejsce w czasach PRL-u. Należeli do nich Grecy razem z Macedończykami oraz Wietnamczycy.

Po klęsce komunistycznego powstania w latach 1948-1950 13216 Greków i Macedończyków znalazło w Polsce azyl20. W 1974 roku po obaleniu rządów wojskowych, a następnie po objęciu w 1981 roku władzy przez partię socjalistyczną Andreasa Papandreu duża grupa Greków wróciła do swojej ojczyzny. W Narodowym Spisie Powszechnym z 2011 roku 3600 osób zadeklarowało narodowość grecką, przy czym 2858 spośród nich zadeklarowało jednocześnie narodowość polską ${ }^{21}$.

Wspomniani uchodźcy greccy w okresie początkowym znaleźli się w Polsce pod opieką naszego państwa, mieli zagwarantowane podstawowe potrzeby egzystencjalne. $\mathrm{Ci}$, którzy pozostali na stałe, dobrze zasymilowali się w wymiarach społecznych i kulturowych. Zaangażowanie Kościoła katolickiego w pomoc tym uchodźcom po ich przybyciu do Polski uniemożliwiały nasze władze (zasadniczo operacja ta była przeprowadzana w wielkiej tajemnicy), a także to, że byli oni wyznawcami komunistycznej ideologii.

Wietnamscy studenci pojawili się w Polsce w roku akademickim 1957/1958. Na początku lat siedemdziesiątych przybyło stamtąd ponad 800 osób. Przyczyną ich wychodźstwa była wojna, a jednocześnie pomoc udzielana Wietnamowi przez państwa bloku wschodniego, do którego należała także Polska. Kolejny napływ Wietnamczyków miał miejsce w 1989 roku. Przesiedlili się oni tutaj z byłej Niemieckiej Republiki Demokratycznej. Dziś Polska jest trzecim krajem w Europie, po Francji i Niemczech, w którym mieszka najwięcej Wietnamczyków. Ich liczbę ocenia się na 40-60 tys., chociaż w spisie w 2011 roku swoją narodowość zdeklarowało tylko 4027 osób ${ }^{22}$.

Wietnamczycy, mimo iż wielu z nich w Polsce zdobyło wykształcenie i tutaj chętnie się osiedla, tworzą zamknięte enklawy, do których dostęp jest utrudniony. Wyjątek stanowią Wietnamczycy wyznania katolickiego. Dobrze funkcjonujące zaplecze stworzyło dla nich Zgromadzenie Słowa Bożego (Mi-

${ }^{20}$ W latach 1948-1949 3105 dzieci; w latach 1949-1950 9282 osoby dorosłe; w latach 1950-1956 829 osób w efekcie łączenia rodzin (por. A. Araszkiewicz, E. Maludzińska, Uchodźcy greccy w Polsce, http://p-ntzp.com/dok/13Araszkiewicz_p.pdf [dostęp: 2.01.2017]).

${ }^{21}$ Por. Główny Urząd Statystyczny, Ludność. Stan i struktura demograficzno-społeczna. Narodowy Spis Powszechny Ludności Mieszkań 2011, Warszawa 2013, s. 91, http://stat.gov.pl/cps/ rde/xbcr/gus/LUD_ludnosc_stan_str_dem_spo_NSP2011.pdf [dostęp: 20.05.2016].

22 Por. Główny Urząd Statystyczny, Ludność. Stan i struktura demograficzno-społeczna. Narodowy Spis Powszechny Ludności Mieszkań 2011, Warszawa 2013, s. 91, http://stat.gov.pl/cps/ rde/xbcr/gus/LUD_ludnosc_stan_str_dem_spo_NSP2011.pdf [dostęp: 20.05.2016]. 
sjonarze Werbiści), zakładając 6 października 2008 roku ośrodek i fundację Ośrodek Migranta Fu Shenfü ${ }^{23}$.

Według raportu ONZ poza granicami swojej ojczyzny pracuje około 50 tys. obywateli Korei Północnej. W Polsce przebywa ich od 480 do 800 . W 2012 roku polskie państwo udzieliło pozwolenie na pracę 509 Koreańczykom. W 2015 roku taką wizę otrzymało tylko 156 osób. W styczniu 2016 roku polski rząd przestał im udzielać pozwoleń na pobyt i pracę. Koreańczycy są tutaj zatrudnieni przeważnie na budowlach, w stoczniach i w ogrodnictwie ${ }^{24}$. Kontrakt zawiera polski kontrahent z koreańską firmą kontrolowaną przez komunistyczny reżim, który $\mathrm{w}$ ten sposób uzupełnia braki dewizowe w swoim budżecie. Według medialnych doniesień przedstawiciele koreańskich władz zabierają tym pracownikom $80-90 \%$ zarobku. O ich niewolniczej pracy i głodowych zarobkach pisały dotychczas gazety i mówiła Helsińska Fundacja Praw Człowieka. Aktualnie sprawą zajął się zespół Slaves to the System. Przewodzi mu prof. Remco Breuker z uniwersytetu w Lejdzie w Holandii. Zespół ten przygotował wstępny raport na temat niewolniczej pracy Koreańczyków, m.in. w Polsce ${ }^{25}$.

Pomoc Kościoła obywatelom koreańskim nie jest możliwa, gdyż dostęp do nich jest bardzo utrudniony. Są oni pilnowani przez funkcjonariuszy służb swojego państwa, nie mogą swobodnie opuszczać miejsca pracy czy zamieszkania. Także oni sami unikają kontaktów z „obcymi”, gdyż łatwo mogą być oskarżeni o zdradę ojczyzny. Kościół mógł jedynie wywierać wpływ na firmy zatrudniające Koreańczyków, żeby zapewniły im właściwe warunki życia i pracy.

Od 1994 roku do Polski zaczęli napływać uchodźcy z Czeczenii (obywatele Rosji; muzułmanie) w efekcie wojen czeczeńsko-rosyjskich. Początkowo były to nieliczne grupy. Największa przybyła w 2013 roku. Azyl otrzymało około 80-90 tys. Czeczenów. Zdecydowana większość z nich wyjechała jed-

${ }^{23}$ Fundacja ta i Ośrodek Migranta Fu Shenfu znajduje się w Warszawie (przy ul. Ostrobramskiej 98). Ośrodek jest otwarty dla wszystkich migrantów, ale dominują w nim Wietnamczycy i Chińczycy (por. Ośrodek Migranta Fu Shenfu, „Portal Ośrodek Migranta Fu Shenfu”, http://www.migrant.p1/ index.php/pl/; [dostęp: 27.12.2016]). Por. także Polska dla imigrantów? - wywiad z dr. Maciejem Stanisławem Zięba o przyszłości polskiej polityki migracyjnej, „Portal Old Caritas Polska”, http:// old.caritas.pl/news.php?id=11459\&d= [dostęp: 25.05 .2016$]$.

${ }^{24}$ Por. R. Kiewlich, P. Weltrowski, Koreańczycy z Pótnocy w trójmiejskich stoczniach, „Portal Trójmiasto.pl", http://www.trojmiasto.pl/wiadomosci/Koreanczycy-z-Polnocy-w-trojmiejskich-stocz niach-n102539.html [dostęp: 29.12.2016].

${ }^{25}$ Por. M. Boonen, K. Boonstra, R. Breuker, Ch. Chung, I. van Gardingen, K. Kwang-cheol, O. Kyuwook, A. van der Veere, North Korean Forced Labour in the EU. The Polish Case: How the Supply of a Captive DPRK Workforce Fits Our Demand for Cheap Labour, "Portal Leiden Asia Centre", http://slavestothesystem.eu/wp-content/uploads/2016/05/NK-forced-labour-first-findings. pdf [dostęp: 15.06.2016]. Autorzy raportu jednocześnie wyjaśniają, że jest to wstępny tekst. Gotowy raport zostanie opublikowany w późniejszym terminie. 
nak do krajów Europy Zachodniej. W Polsce pozostało około 6-8 tys. Osoby te zasadniczo dobrze się tutaj zaaklimatyzowały ${ }^{26}$, chociaż nieliczni przedstawiciele młodego pokolenia zostali zwerbowani przez Państwo Islamskie, zbierali środki na jego działalność terrorystyczną lub wyjechali do Syrii ${ }^{27}$.

W ostatnich latach notuje się masowy napływ do Polski Ukraińców. Według spisu powszechnego przeprowadzonego w 2011 roku narodowość ukraińską deklarowało 51001 osób, przy czym 27630 osób podało ją jako jedyną ${ }^{28}$. W roku 2016 liczbę Ukraińców mieszkających w Polsce szacuje się już na około jeden milion, przy czym 600 tys. pracuje tutaj legalnie ${ }^{29}$. W 2016 roku byli największą grupą ubiegającą się o prawo pobytu w Polsce (wyprzedzając Wietnamczyków, Białorusinów, Chińczyków, Rosjan i chrześcijańskich uchodźców z Syrii) ${ }^{30}$. Początkowo sytuacja tych migrantów nie stanowiła specjalnego wyzwania społecznego. W ostatnim czasie zaczęto jednak mówić o przypadkach wyzysku przez polskich pracodawców, w efekcie czego 15 czerwca 2016 roku grupa Ukraińców założyła własny związek zawodowy. Prawnej pomocy udzielił im OPZZ ${ }^{31}$.

26 Por. Ł. Lubański, Czeczeni nie sprawiaja w Polsce problemów, „Portal: rp.pl”, http:// www.rp.p1/Wiadomosci/309219781-Czeczeni-nie-sprawiaja-w-Polsce-problemow.html\#ap-1 [dostęp: 29.12.2016]; K. Zuchowicz, Polska przyjęła już ponad 80 tysięcy Czeczenów i wciąż przyjmuje następnych. Czy komuś to przeszkadza?, „Portal dyskusyjny: Na:Temat”, http://natemat. pl/155107,polska-przyjela-juz-blisko-90-tysiecy-uchodzcow-z-czeczenii-dzis-zostala-ich-tylkogarstka-bo-nie-chcieli-u-nas-zostac [dostęp: 29.12.2016].

27 Por. A. Borowski, Jak to z Czeczenami w Polsce byto, „Portal: wPolityce”, http://wpolityce. pl/spoleczenstwo/265691-jak-to-z-czeczenami-w-polsce-bylo-adam-borowski-to-byly-samotnekobiety-z-dziecmi-starcy-i-ranni-mlodych-mezczyzn-nie-bylo-bo-walczyli-za-swoj-kraj?strona=1-2 [dostęp: 29.12.2016]; Redakcja Radia Zet, Czeczeni zbierali pieniądze na zamachy Państwa Islamskiego, „Portal radio.zet”, http://wiadomosci.radiozet.pl/Wiadomosci/Kraj/Polska-Czeczenizbierali-pieniadze-na-zamachy-Panstwa-Islamskiego-00027846 [dostęp: 29.12.2016].

${ }^{28}$ Por. Główny Urząd Statystyczny, Narodowy Spis Powszechny Ludności i Mieszkań 2011. Ludność. Stan i struktura demograficzno-spoleczna, Warszawa 2013, s. 91, http://stat.gov.pl/cps/rde/ xbcr/gus/LUD_ludnosc_stan_str_dem_spo_NSP2011.pdf. [dostęp: 27.12.2016].

29 Por. Milion Ukraińców w Polsce? Firmy szukaja pracowników, „Portal TVP.INFO” 23.09.2016, http://www.tvp.info/27050960/milion-ukraincow-w-polsce-firmy-szukaja-pracownikow [dostęp: 27.12.2016]; G. Zawadka, Ukraińcy chca pracować w Polsce i ratuja polska gospodarkę, „Portal RP.pl” [Rzeczpospolita] 27.10.2016, http://www.rp.pl/Dane-gospodarcze/310279833Ukraincy-chca-pracowac-w-Polsce-i-ratuja-polska-gospodarke.html\#ap-1 [dostęp: 27.12.2016]; J. Wilczak, Niewidzialni. Milion Ukraińców w Polsce: Kim sq? Gdzie pracuja?, „Portal Polityka”. 14.06.2016. http://www.polityka.pl/tygodnikpolityka/spoleczenstwo/1664626,1,milion-ukraincoww-polsce-kim-sa-gdzie-pracuja.read [dostęp: 27.12.2016].

30 Por. Urząd do Spraw Cudzoziemców, Podsumowanie roku [2016] ustawy o cudzoziemcach, s. 4-5, http://udsc.gov.pl/statystyki/raporty-specjalne/podsumowanie-roku-ustawy-o-cudzoziemcach/ [dostęp: 02.01.2017].

31 Por. Ukraińcy pracujący w Polsce będa mieli swój zwiazek zawodowy? Powoła go OPZZ, „Portal Biznes.Onet.pl”, http://biznes.onet.pl/praca/zwiazek-zawodowy-pracownikow-ukrainskichw-polsce-pomysl-opzz/jjpqrx [dostęp: 27.05.2016]; także Pracownicy z Ukrainy stworza w Polsce zwiazki zawodowe? Ich prawa sq naruszane, „Portal Polskie Radio.pl”, http://www.polskieradio. 
Los migrantów nie jest obojętny polskiemu Kościołowi. W ślad za inicjatywami Stolicy Apostolskiej także Konferencja Episkopatu Polski powołała najpierw Komisję do spraw Duszpasterstwa Turystycznego ${ }^{32}$. Jej pierwszym przewodniczącym był bp Julian Groblicki, biskup pomocniczy archidiecezji krakowskiej. Następnie w miejsce powyższej Komisji została ustanowiona Rada ds. Migracji, Turystyki i Pielgrzymek. Miało to miejsce na 283. Zebraniu Plenarnym Konferencji Episkopatu Polski w Warszawie od 30 kwietnia do 2 maja 1996 roku $^{33}$. Aktualnie przewodniczącym Rady jest ks. bp Krzysztof Zadarko, biskup pomocniczy diecezji koszalińsko-kołobrzeskiej.

Misja wspomnianej Rady jest inspirowana słowami Pana Jezusa „byłem przybyszem, a przyjęliście Mnie” (Mt 25,35) oraz przestrogą „Idźcie precz ode Mnie, przeklęci [...], bo byłem przybyszem, a nie przyjęliście Mnie" (Mt 25,41-43). Źródłem ważnych wskazań dla Rady jest nauczanie Stolicy Apostolskiej, w tym motu proprio papieża Pawła VI Apostolicae caritatis $^{34}$, papieskie orędzia na Światowy Dzień Migranta i Uchodźcy ${ }^{35}$ oraz przesłania Papieskiej Rady ds. Duszpasterstwa Migrantów i Podróżujących: Instrukcja «Erga migrantes caritas Christi» ${ }^{36}$ oraz Przyjęcie Chrystusa w uchodźcach i przymusowo przesiedlonych. Wytyczne duszpasterskie ${ }^{37}$.

$\mathrm{Z}$ uwagi na to, że dotychczas Polska nie stała się celem masowej migracji, nie były tutaj rozwijane szerokie programy pomocy dla migrantów. Działalność taką poza granicami kraju prowadziła jednak Caritas Polska ${ }^{38}$ oraz Pomoc Kościołowi w Potrzebie (Kirche in Not - międzynarodowa organizacja mająca swój oddział w Polsce) $)^{39}$. Los migrantów stał się przedmiotem szczególnej troski wspomnianej Rady Konferencji Episkopatu ds. Migracji, Turystyki i Pielgrzymek od 2015 roku, a więc od czasu napływu do Europy wiel-

p1/42/275/Artykul/1623678,Pracownicy-z-Ukrainy-stworza-w-Polsce-zwiazki-zawodowe-Ichprawa-sa-naruszane [dostęp: 27.05.2016].

32 Por. J. Dyduch, Kościelne struktury duszpasterstwa ,,Ludzi w drodze”, „Notificationes e Curia Metropolitana Cracoviensi” 19(1982) nr 7-9, s. 196-205; M. Ostrowski, Struktury duszpasterstwa turystycznego, http://www.pastoralna.pl/files/323\%20Struktury\%20duszpasterstwa\%20turystyczne go.pdf [dostęp: 02.01.2017].

33 Por. „Biuletyn KAI” 1996 nr 19(216) (z 7.05.1996), s. 4-5.

34 Por. Paweł VI, Motu proprio Apostolicae caritatis, “Acta Apostolicae Sedis" 62(1970) nr 4 , s. $193-197$.

35 Por. Światowy Dzień Migranta i Uchodźcy, „Portal Instytut Duszpasterstwa Emigracyjnego im. Kard. Augusta Hlonda w Poznaniu", http://www.emigracja.chrystusowcy.pl/index.php/dziemigranta [dostęp: 28.12.2016].

${ }^{36}$ Papieska Rada do Spraw Duszpasterstwa Migrantów i Podróżujących, Instrukcja Erga migrantes caritas Christi, Rzym 2004.

37 Papieska Rada do Spraw Duszpasterstwa Migrantów i Podróżujących, Przyjęcie Chrystusa w uchodźcach i przymusowo przesiedlonych. Wytyczne duszpasterskie, Rzym 2013.

${ }^{38}$ Por. Caritas Polska, Działania na świecie, http://www.caritas.pl/zagranica/ [dostęp: 02.01. 2017].

39 Por. Pomoc Kościołowi w Potrzebie, http://pkwp.org/ [dostęp: 02.10.2017]. 
kich rzesz uchodźców z Bliskiego Wschodu, Afryki (zwłaszcza z Syrii, Iraku, Sudanu i Erytrei) i zza Bugu. Można wyróżnić dwie płaszczyzny zaangażowań Rady. Z jednej strony odwołuje się ona do ludzkiej wrażliwości, aby nikomu nie był obcy „chrześcijański obowiązek pomocy uchodźcom ratującym swoje życie z krajów objętych działaniami wojennymi lub prześladowaniami religijnymi" 40 . Z drugiej strony Rada wzywa osoby pełniące odpowiedzialne funkcje polityczne do przeciwdziałania przyczynom uchodźstwa oraz do zapewnienia migrantom godnych warunków życia. Nie są to apele populistyczne czy też mające na celu uspokojenie sumień, gdyż towarzyszą im konkretne działania krajów, od których oczekuje się przyjęcia migrantów, mające na celu zapewnienie im bezpieczeństwa i społecznych potrzeb ${ }^{41}$.

W efekcie prowadzonych dyskusji członkowie Rady widzą też dwuwymiarowe rozwiązanie problemu migracji. Pierwszym z nich jest troska o pokój, gdyż wojna jest jednym z głównych czynników napędzających ruchy migracyjne. Drugi wymiar to promocja poszanowania godności człowieka wraz z dialogiem z innymi kulturami i religiami. Staraniom tym powinna towarzyszyć gościnność dla wszystkich, którzy szukają schronienia czy też lepszego życia w naszym kraju, bez względu na religię i wyznanie. Komisja podkreśla także, że „ludzka sprawiedliwość i chrześcijańska gościnność stoją w sprzeczności z traktowaniem przybyszów jedynie jako taniej siły roboczej, podejmowanej w fatalnych warunkach mieszkania, pracy i wynagrodzenia ${ }^{42}$ ".

Jak wyżej podkreślono, ważnym aspektem działalności jest pomoc mieszkańcom regionów objętych zbrojnymi konfliktami i materialnym ubóstwem, a także osobom, które przebywają w obozach dla uchodźców lub w szpitalach polowych. Realizują ją wspomniane Caritas Polska oraz Pomoc Kościołowi w Potrzebie.

W końcu Rada uwrażliwia na apele adresowane przez Stolicę Apostolską do struktur politycznych o podjęcie działań będących w stanie powstrzymać procesy generujące migrację oraz o sprawiedliwy rozdział migrantów, tak $\mathrm{w}$ państwach europejskich, jak i w innych regionach świata, nie pomijając przy tym gwarancji dla bezpieczeństwa i odpowiedzialnej polityki społecznej krajów docelowych ${ }^{43}$.

${ }^{40}$ Konferencja Episkopatu Polski, Chrześcijański obowiąek pomocy uchodźcom, http:// episkopat.pl/chrzescijanski-obowiazek-pomocy-uchodzcom/ [dostęp: 19.06.2015].

${ }^{41}$ Por. Chrześcijański obowiazek pomocy uchodźcom, „Portal Katolik.pl”, http://www.katolik. pl/24897,794.druk [dostęp: 27.05.2016].

${ }^{42}$ Konferencja Episkopatu Polski, Komunikat Rady Konferencji Episkopatu Polski ds. Migracji, Turystyki i Pielgrzymek, http://episkopat.pl/komunikat-rady-konferencji-episkopatu-polskids-migracji-turystyki-i-pielgrzymek/ [dostęp: 19.06.2015].

${ }^{43}$ Por. K. Zadarko, Komunikat Rady Konferencji Episkopatu Polski ds. Migracji, Turystyki i Pielgrzymek, „Portal Katolik.pl”, http://www.katolik.pl/24897,794.druk [dostęp: 27.05.2016]. 
Należy też zauważyć, że uwaga Rady nie kieruje się wyłącznie w stronę powszechnie znanych miejsc niepokojów i ubóstwa. Bardzo ważny dla Rady jest także temat repatriacji Polaków i osób polskiego pochodzenia ze Wschodu oraz ich integracja społeczna. Orientacja ta jest podyktowana zasadami ,porządku miłości”, który w pierwszej kolejności obliguje do przychodzenia z pomocą osobom bliskim i rodakom, a następnie wszystkim innym znajdującym się $\mathrm{w}$ podobnej potrzebie.

Partykularnym wyrazem pomocy udzielanej ofiarom wojny na Bliskim Wschodzie była wizyta 17-22 lutego 2016 roku przewodniczącego Konferencji Episkopatu Polski, abpa Stanisława Gądeckiego, w towarzystwie ks. Waldemara Cisło, dyrektora polskiego oddziału Pomoc Kościołowi w Potrzebie w Syrii. Delegacja przekazała biskupom syryjskim opiekującym się uchodźcami chrześcijańskimi 4,2 mln złotych ${ }^{44}$.

W szerszym wymiarze polscy biskupi zajęli się kwestią uchodźców podczas zebrania plenarnego Konferencji Episkopatu w Poznaniu w dniach 14-16 kwietnia 2016 roku. Dyskusję zainicjował przewodniczący Rady do spraw Migracji, Turystyki i Pielgrzymek, bp Krzysztof Zadarko. Ostateczne stanowisko biskupów zostało przedstawione w Komunikacie końcowym Zebrania Plenarnego Konferencji Episkopatu Polski, w którym stwierdzono:

Wobec kryzysu uchodźczego w Europie biskupi przypominają, że uchodźcy powinni być traktowani w duchu ewangelicznej otwartości, solidarności, odpowiedzialności i poszanowania godności osoby. Główna inicjatywa i odpowiedzialność za proces przyjęcia szukających azylu spoczywa na władzy świeckiej, w której gestii leży zagwarantowanie uchodźcom bezpieczeństwa i podstawowych świadczeń. Wobec tego wyzwania strona kościelna wyraża gotowość współpracy w ramach Caritas Polska. Biskupi proszą wiernych o modlitwę w intencji pokoju, bez którego nie ustaną główne przyczyny fali uchodźców na świecie ${ }^{45}$.

Temat uchodźców powrócił w czasie posiedzenia plenarnego Konferencji Episkopatu Polski w Warszawie w dniach 7-8 czerwca 2016 roku. Biskupi ustosunkowali się do Przesłania Prezydiów Konferencji Episkopatu Polski i Polskiej Rady Ekumenicznej w sprawie uchodźców. Dokument przedstawia

${ }^{44}$ Por. S. Gądecki, Zobaczyliśmy bardzo smutny obraz wojny, „Portal Niedziela”, http://www. niedziela.pl/artykul/20873/Abp-Gadecki-Zobaczylismy-bardzo-smutny [dostęp: 01.06. 2016]; por. także „Portal E-Kai.pl”. Przewodniczacy Episkopatu Polski o wizycie w Syrii. 23.02.2016, http:// ekai.pl/wydarzenia/temat_dnia/x97198/przewodniczacy-episkopatu-polski-o-wizycie-w-syrii/ [dostęp: 01.06.2016].

${ }^{45}$ Konferencja Episkopatu Polski, Komunikat z 372. Zebrania Plenarnego Konferencji Episkopatu Polski. Gniezno-Poznań, 14-16 kwietnia 2016 r., „Portal Episkopat.pl”, http://episkopat. pl/dokumenty/komunikaty_zp_kep/7316.1,Komunikat_z_372_Zebrania_Plenarnego_Konferencji_ Episkopatu_Polski.html [dostęp: 20.05.2016]. 
ogólnie kryzys migracyjny i przypomina obowiązek chrześcijan przychodzenia z pomocą uchodźcom. Kościoły winny kształtować serca wiernych tak, by byli zdolni do praktykowania miłosierdzia, nie zapominając, że nasz kraj był wielokrotnie miejscem schronienia dla osób prześladowanych, a z drugiej strony także nasi rodacy w czasach komunistycznego zniewolenia doświadczali gościnności w demokratycznych krajach Europy Zachodniej. Dziś wierni wspomnianych Kościołów winni współpracować z organami władzy państwowej i organizacji społecznej w humanitarnych działaniach na rzecz uchodźców. W pomocy tej nie chodzi tylko o ich przyjmowanie w naszym kraju, ale $\mathrm{w}$ równym stopniu o uruchomienie konkretnych programów wsparcia $\mathrm{w}$ ich ojczyznach.

W efekcie dyskusji polscy biskupi uznali za najlepsze rozwiązanie problemu uchodźców zorganizowanie przez Caritas Polska tak zwanego „korytarza humanitarnego". Polega on na rozpoznaniu i przygotowaniu przez Caritas osób i rodzin znajdujących się w najtrudniejszej sytuacji, a pragnących przybyć do Polski i tutaj zamieszkać. Byłby one „zweryfikowane” przez nasze służby i po udzieleniu im odpowiednich wiz przetransportowane do Polski samolotem. Warto odnotować, że takim programem zostały już objęte 384 osoby, w tym 203 z Syrii $^{46}$. Rozpatrzono jednak zaledwie 10\% złożonych wniosków. Udzielanie tego typu pomocy przez Polskę jest trudne, ponieważ wielu uchodźców nie chce pozostać tutaj na stałe, a nasze państwo traktuje jako przystań w drodze do krajów Europy Zachodniej.

W dyskusjach nad skutecznymi formami pomocy dla mieszkańców krajów niszczonych przez wojny i konflikty wyrażane jest przekonanie, że najwłaściwszym programem jest wsparcie osób żyjących w bardzo trudnych warunkach w ich ojczyźnie. Stąd biskupi uznają, że stosowną formą działania będzie objęcie przez polskie rodziny, parafie czy inne organizacje dobroczynne patronatu nad rodzinami w ich ojczyźnie lub w miejscu ich schronienia. W związku z tym Episkopat Polski zamierza skorzystać z pośrednictwa Caritasu Libanu, Jordanii, Syrii i Iraku.

Kolejną formą pomocy ma być program obejmujący rodziny, które w wyniku wojny musiały opuścić swoje domy i osiedliły się w innych krajach Bliskiego Wschodu, na przykład w Jordanii czy w Libii, gdzie odpłatnie wynajmują mieszkania i żyją w bardzo trudnych warunkach. Będzie to materialne i finansowe wsparcie tych osób ${ }^{47}$.

46 Por. „Przyjechaliśmy do Polski z nadzieja, że będziemy tutaj mieć druga ojczyznę”. Syryjscy uchodźcy przylecieli do Warszawy, TVP.INFO. 11.07.2015, http://www.tvp.info/20793010/ przyjechalismy-do-polski-z-nadzieja-ze-bedziemy-tutaj-miec-druga-ojczyzne-syryjscy-uchodzcyprzylecieli-do-warszawy [dostęp: 02.01.2017].

${ }^{47}$ Por. Konferencja Episkopatu Polski, ŚDM, rodzina, uchodźcy, związi niesakramentalne zakończyło się 373. Zebrania Plenarnego Konferencji Episkopatu Polski. Warszawa 7-8.06.2016, 
Powyższe dyskusje podsumowuje Komunikat z 373. Zebrania Plenarnego Konferencji Episkopatu Polski, w którym oznajmiono:

Konferencja Episkopatu Polski zajęła się ponownie tragiczną sytuacją uchodźców, którzy z powodu konfliktów zbrojnych i prześladowań zostali zmuszeni do opuszczenia swoich rodzinnych domów i pozbawieni niezbędnych środków do godziwego życia. Kościół w Polsce będzie w dalszym ciągu udzielał wsparcia tym osobom. Wśród wielu form pomocy należy podkreślić działalność Caritas Polska, która troszczy się zarówno o osoby żyjące w rejonach objętych wojną, jak również wychodzi naprzeciw potrzebom ludzi szukających schronienia w Polsce ${ }^{48}$.

Przedstawiona analiza pozwala stwierdzić, że biskupi obydwu sąsiadujących ze sobą państw czują się bardzo odpowiedzialni za ludzi pokrzywdzonych przez los i szukających schronienia w Europie. Stąd też nie ma rozbieżności między stanowiskami episkopatów obydwu Kościołów w omawianej kwestii. Opinię taką prezentuje nie tylko strona Polska, ale również przedstawiciel strony niemieckiej. Arcybiskup Bambergu Ludwik Schick stwierdził w wywiadzie udzielonym Katolickiej Agencji Informacyjnej: „W kwestii migrantów nie ma między nami żadnych zasadniczych różnic. [...] Jesteśmy zgodni, że jako chrześcijanie musimy przyjmować wszystkich ludzi pozbawionych ojczyzny, dając im możliwość spokojnego życia i rozwoju"49.

Pewne różnice można zauważyć w praktycznej realizacji założeń doktrynalnych. Są one związane z różną liczbą napływających do tych państw migrantów, z krajami ich pochodzenia oraz praktycznymi możliwościami obydwu Kościołów. Powtarzanie, że Polska jest przeciwna przyjmowaniu emigrantów wynika $\mathrm{z}$ niewiedzy, w jakim stopniu Polska okazuje pomoc własnym repatriantom oraz migrantom $z$ byłych republik radzieckich (problem ten statystycznie tylko w znikomym stopniu dotyczy państwa niemiec-

\footnotetext{
„Portal E-Kai”, https://ekai.pl/wydarzenia/temat_dnia/x100505/sdm-rodzina-uchodzcy-zwiazki-nie sakramentalne-zakonczylo-sie-zebrania-kep/ [dostęp: 07.06.2016].

${ }^{48}$ Konferencja Episkopatu Polski, Komunikat z 373. Zebrania Plenarnego Konferencji Episkopatu Polski. Warszawa 7-8.06.2016, http://episkopat.pl/dokumenty/komunikaty_zp_kep/75 01.1,Komunikat_z_373_Zebrania_Plenarnego_Konferencji_Episkopatu_Polski.html [dostęp: 8.06. 2016].

${ }^{49}$ K. Tomasik, Arcybiskup Bambergu o uchodźcach, ŚDM i relacjach polsko-niemieckich [wywiad z abp Ludwikiem Schickiem], „Portal E-Kai”, https://ekai.pl/wydarzenia/temat_dnia/x 100484/arcybiskup-bambergu-o-uchodzcach-sdm-i-relacjach-polsko-niemieckich/. 08.06.2016 [dostęp: 05.06.2016].
} 
kiego: Niemców powracający z byłych republik radzieckich i obywateli byłych republik radzieckich szukający pracy w Niemczech), a także że przyjęła już około 1,5 mln migrantów różnej proweniencji. Polska kieruje się wyraźnie zasadą porządku miłości, troszcząc się na pierwszym miejscu o swoich rodaków i wschodnich sąsiadów. Na drugim miejscu, jako członek Unii Europejskiej, włącza się w działania na rzecz uchodźców ze wspomnianych krajów Bliskiego Wschodu, z Czeczenii oraz Afryki, przyznając priorytet mieszkańcom krajów głodujących oraz uwikłanym w różne konflikty zbrojne. W końcu zakres pomocy państwa polskiego wynika z jego możliwości ekonomicznych, a jego zaangażowania są zgodne $\mathrm{z}$ duchem chrześcijańskim i nie przeczą zasadom Ewangelii, na co zwrócił uwagę papież Franciszek w czasie spotkania z polskimi biskupami w krakowskiej katedrze na początku pielgrzymki do Polski w 2016 roku: „Sądzę, że każdy kraj musi zobaczyć, w jaki sposób i kiedy [może przyjść z pomocą migrantom]. Nie wszystkie kraje są równe; nie wszystkie kraje mają takie same możliwości. [...] Nie można dać odpowiedzi uniwersalnej, ponieważ gościnność zależy od sytuacji danego kraju" ${ }^{\circ 0}$. Aktualnie w Polsce przebywa już około 1,5 miliona migrantów.

\section{THE POSITION OF GERMAN AND POLISH EPISCOPATES TOWARDS THE MASS INFLUX OF MIGRANTS}

\section{Summary}

The author compares the attitude of the German and Polish episcopates to the problem of the reception of migrants. In both cases the first historical aspect together with statistical data, then the doctrinal position and specific involvement is presented. The analyses enable to establish that both episcopates equally feel responsibility for migrants and equally commit themselves to assistance for them. Some differences can be noticed in practical realization of doctrinal assumptions. They are connected with different quantities of migrants coming to these countries, with countries of their origin and with practical possibilities of both countries and Churches. Repeated conviction that Poland is against the reception of emigrants rises out of ignorance how Poland helps to her repatriates, to migrants from former Soviet republics, from Near East and Africa. There are already about 1,5 million migrants in Poland.

Słowa kluczowe: migranci; Episkopat Polski; Episkopat Niemiec

Keywords: migrants; German Episcopate; Polish Episcopate

${ }^{50}$ Franciszek, Błogostawieni miłosierni. Słowa do młodych, Kraków 2016, s. 48-49. 


\section{BIBLIOGRAFIA}

\section{Literatura źródłowa}

Bistum Hildesheim, Fünf Sprachen in einem Gebetbuch. Kirchen geben Andachtsbuch für christliche Flüchtlinge heraus, „Portal Bistum Hildesheim”, https://www.bistum-hildesheim.de/bistum/nachrichten/artikel/news-title/fuenf-sprachen-in-einem-gebetbuch-6585/ [dostęp: 01.06. 2016].

Deutsche Bischofskonferenz, Flüchtlingshilfe der katholischen Kirche, „Portal Deutsche Bischofskonferenz", http:/www.dbk.de/fluechtlingshilfe/home/ [dostęp: 12.05.2016; 04.01.2017].

Deutsche Bischofskonferenz, XII. Jahrestagung Illegalität in Berlin beendet. Die Wahrung der Menschenwürde ist kein Luxusgut, sondern Ausgangs- und Zielpunkt unserer rechtsstaatlichen Ordnung, „Portal Deutsche Bischofskonferenz”, http://www.dbk.de/presse/details/?suchbegriff=m igration\&presseid=3064\&cHash=fbdeec6a0eea5f101609c06a13afc301 [dostęp: 15.05.2016].

Deutsche Bischofkonferenz, Leitsätze des kirchlichen Engagements für Flüchtlinge. Kloster Schöntal. 18. Februar 2016, „Portal Deutsche Bischofskonferenz”, http://www.dbk.de/fileadmin/redaktion/diverse_downloads/presse_2016/2016-031-Anlage-1-Leitsaetze-FVV-Pressebericht. pdf [dostęp: 29.12.2016].

Deutsche Bischofskonferenz. Pressemitteilung, Die Alternative zur Rettung ist der Tod. 27.10.2014, „Portal Bistum Erfurt”, http://www.bistum-erfurt.de/aktuelles/archiv-2014/bischof-trelle-zurseenotrettung-von-fluechtlingen.html [dostęp: 27.05.2016].

Deutsche Bischofskonferenz, Situation in Flüchtlingseinrichtungen. Umfrage in den deutschen Bistümern. 10.05.2016, „Portal Deutsche Bischofskonferenz”, http://www.dbk.de/presse/details/?p resseid=3110\&cHash=903aeb812de6800aa679d8cb3d42cadd [dostęp: 12.05 .2015$]$.

Erzbistum Berlin, Hilfe für Flüchtlinge im Erzbistum Berlin, „Portal Erzbistum Berlin”, http://www. erzbistumberlin.de/hilfe/fluechtlinge-im-erzbistum-berlin/ [dostęp: 01.06.2016].

Franciszek, Błogosławieni miłosierni. Słowa do młodych, Wyd. „M”, Kraków 2016.

Franciszek, Homily. Visit to Lampedusa. 8 July 2013, "Portal Vatikan.va", http://w2.vatican.va/content/francesco/it/homilies/2013/documents/papa-francesco_20130708_omelia-lampedusa.html [dostęp: 12.05.2016].

Franciszek, Address of the Holy Father. Visit at the European Parliament. Strasbourg 25.11.2014, "Portal Jezuici.pl", http://jezuici.pl/wp-content/uploads/2014/11/Franciszek-przemowienie-wParlamencie-Europejskim.pdf [dostęp: 12.05.2016].

Gądecki S., Zobaczyliśmy bardzo smutny obraz wojny, „Portal Niedziela”, http://www.niedziela.pl/ artykul/20873/Abp-Gadecki-Zobaczylismy-bardzo-smutny [dostęp: 01.06.2016].

Konferencja Episkopatu Polski, Komunikat z 283 Zebrania Plenarnego Konferencji Episkopatu Polski. Warszawa, 30.04.-02.05.1996, „Biuletyn KAI” 1996 nr 19(216) (z 7.05.1996), s. 4-5.

Konferencja Episkopatu Polski, Komunikat z 372. Zebrania Plenarnego Konferencji Episkopatu Polski. Gniezno-Poznań, 14-16 kwietnia 2016 r., ,Portal Episkopat.pl”, http://episkopat.pl/ dokumenty/komunikaty_zp_kep/7316.1,Komunikat_z_372_Zebrania_Plenarnego_Konferencji_Episkopatu_Polski.html [dostęp: 20.05.2016].

Konferencja Episkopatu Polski, Komunikat z 373. Zebrania Plenarnego Konferencji Episkopatu Polski. Warszawa, 7-8.06.2016, http://episkopat.pl/dokumenty/komunikaty_zp_kep/7501.1,Komunikat_z_373_Zebrania_Plenarnego_Konferencji_Episkopatu_Polski.html [dostęp: 8.06.2016].

Konferencja Episkopatu Polski, ŚDM, rodzina, uchodźcy, zwiąki niesakramentalne - zakończyło się 373. Zebrania Plenarnego Konferencji Episkopatu Polski. Warszawa, 7-8.06.2016, „Portal E-Kai”, https://ekai.pl/wydarzenia/temat_dnia/x100505/sdm-rodzina-uchodzcy-zwiazkiniesakramentalne-zakonczylo-sie-zebrania-kep/ [dostęp: 07.06.2016].

Marx R., Nie wolno odsyłać uchodźców, „Portal Interia.pl”, http://fakty.interia.pl/raporty/raport-imigranci-z-afryki/informacje/news-kardynal-marx-nie-wolno-odsylac-uchodzcow,nId, 2209926\#utm_source=paste\&utm_medium=paste\&utm_campaign=firefox [dostęp: 30.05.2016]. 
Papieska Rada do Spraw Duszpasterstwa Migrantów i Podróżujących, Instrukcja Erga migrantes caritas Christi, Rzym 2004.

Papieska Rada do Spraw Duszpasterstwa Migrantów i Podróżujących, Przyjęcie Chrystusa w uchodźcach i przymusowo przesiedlonych. Wytyczne duszpasterskie, Rzym 2013.

Paweł VI, Motu proprio Apostolicae caritatis, "Acta Apostolicae Sedis" 62(1970) nr 4, s. 193-197.

„Portal E-Kai.pl”, Przewodniczacy Episkopatu Polski o wizycie w Syrii. 23.02.2016, http://ekai.pl/ wydarzenia/temat_dnia/x97198/przewodniczacy-episkopatu-polski-o-wizycie-w-syrii/ [dostęp: 01.06.2016].

Zadarko K., Komunikat Rady Konferencji Episkopatu Polski ds. Migracji, Turystyki i Pielgrzymek, „Portal Katolik.pl”, http://www.katolik.pl/24897,794.druk [dostęp: 27.05.2016].

\section{Literatura pomocnicza}

Anzahl der Ausländer in Deutschland nach Herkunftsland in den Jahren 2014 und 2015, „Portal Statista - Das Statistik-Portal", http://de.statista.com/statistik/daten/studie/1221/umfrage/anzahl-der-auslaender-in-deutschland-nach-herkunftsland/ [dostęp: 30.05.2016].

Araszkiewicz A., Maludzińska E., Uchodźcy greccy w Polsce, http://p-ntzp.com/dok/13Araszkiewicz_p.pdf [dostęp: 2.01.2017].

Boonen M., Boonstra K., Breuker R., Chung Ch., Van Gardingen I., Kwang-cheol K., Kyuwook O., Van der Veere A., North Korean Forced Labour in the Eu. The Polish Case: How the Supply of a Captive DPRK Workforce Fits Our Demand for Cheap Labour, "Portal Leiden Asia Centre", http://slavestothesystem.eu/wp-content/uploads/2016/05/NK-forced-labour-first-findings.pdf [dostęp: 15.06.2016].

Borowski A., Jak to z Czeczenami w Polsce było, „Portal: wPolityce”, http://wpolityce.pl/spoleczenstwo/265691-jak-to-z-czeczenami-w-polsce-bylo-adam-borowski-to-byly-samotne-kobiety-zdziecmi-starcy-i-ranni-mlodych-mezczyzn-nie-bylo-bo-walczyli-za-swoj-kraj?strona=1-2 [dostęp: 29.12.2016].

Caritas Polska, Działania na świecie, http://www.caritas.pl/zagranica/ [dostęp: 02.01.2017].

Chrześcijański obowiązek pomocy uchodźcom, „Portal Katolik.pl”, http://www.katolik.pl/24897,794. druk [dostęp: 27.05.2016].

Dyduch J., Kościelne struktury duszpasterstwa „Ludzi w drodze”, „Notificationes e Curia Metropolitana Cracoviensi" 19(1982) nr 7-9, s. 196-205.

Główny Urząd Statystyczny, Ludność. Stan i struktura demograficzno-społeczna. Narodowy Spis Powszechny Ludności Mieszkań 2011, Warszawa 2013, s. 91, http://stat.gov.pl/cps/rde/xbcr/ gus/LUD_ludnosc_stan_str_dem_spo_NSP2011.pdf [dostęp: 20.05.2016].

Grajewski A., My mieliśmy rację, „Gość Niedzielny” 93(2016) nr 20 (15.05.2016), s. 11.

Jeder Asylsuchende hat Anspruch auf ein individuelles, faires und unvoreingenommenes Verfahren. Spitzentreffen zwischen den Kirchen und dem Bundesamt für Migration und Flüchtlinge. Nürnberg 11.03.2016, „Portal Deutsche Bischofskonferenz”, http://www.dbk.de/presse/details/?su chbegriff $=$ migration $\&$ presseid $=3074 \& \mathrm{cHash}=\mathrm{d} 9 \mathrm{c} 5 \mathrm{~b} 52 \mathrm{e} 81 \mathrm{fbcfc} 3040 \mathrm{e} 74390 \mathrm{~b} 323 \mathrm{f32} \quad$ [dostęp: 14.05.2016].

Kiewlich R., Weltrowski P., Koreańczycy z Pólnocy w trójmiejskich stoczniach, „Portal Trójmiasto. pl”, http://www.trojmiasto.pl/wiadomosci/Koreanczycy-z-Polnocy-w-trojmiejskich-stoczniachn102539.html [dostęp: 29.12.2016].

Lubański Ł., Czeczeni nie sprawiaja w Polsce problemów, „Portal: rp.pl”, http://www.rp.pl/Wia domosci/309219781-Czeczeni-nie-sprawiaja-w-Polsce-problemow.html\#ap-1 [dostęp: 29.12. 2016].

Milion Ukraińców w Polsce? Firmy szukaja pracowników, „Portal TVP.INFO” 23.09.2016, http:// www.tvp.info/27050960/milion-ukraincow-w-polsce-firmy-szukaja-pracownikow [dostęp: 27.12. 2016]. 
Ostrowski M., Struktury duszpasterstwa turystycznego, http://www.pastoralna.pl/files/323\%20Struk tury\%20duszpasterstwa\%20turystycznego.pdf [dostęp: 02.01.2017].

Ośrodek Migranta Fu Shenfu, „Portal Ośrodek Migranta Fu Shenfu”, http://www.migrant.pl/index. $\mathrm{php} / \mathrm{pl} / ;$ [ [dostęp: 27.12.2016].

Polska dla imigrantów? - wywiad z dr. Maciejem Stanisławem Zięba o przyszłości polskiej polityki migracyjnej, „Portal Old Caritas Polska”, http://old.caritas.pl/news.php?id=11459\&d= [dostęp: 25.05.2016].

Pomoc Kościołowi w Potrzebie, http://pkwp.org/ [dostęp: 02.10.2017].

Pracownicy z Ukrainy stworza w Polsce zwiazki zawodowe? Ich prawa sq naruszane, „Portal Polskie Radio.pl", http://www.polskieradio.pl/42/275/Artykul/1623678,Pracownicy-z-Ukrainy-st worza-w-Polsce-zwiazki-zawodowe-Ich-prawa-sa-naruszane [dostęp: 27.05.2016].

„Przyjechaliśmy do Polski z nadzieją, że będziemy tutaj mieć druga ojczyznę”. Syryjscy uchodźcy przylecieli do Warszawy, TVP.INFO. 11.07.2015, http://www.tvp.info/20793010/przyjechalismy-do-polski-z-nadzieja-ze-bedziemy-tutaj-miec-druga-ojczyzne-syryjscy-uchodzcyprzylecieli-do-warszawy [dostęp: 02.01.2017].

Redakcja Radia Zet, Czeczeni zbierali pieniadze na zamachy Państwa Islamskiego, „Portal radio. zet", http://wiadomosci.radiozet.pl/Wiadomosci/Kraj/Polska-Czeczeni-zbierali-pieniadze-nazamachy-Panstwa-Islamskiego-00027846 [dostęp: 29.12.2016].

Światowy Dzień Migranta i Uchodźcy, „Portal Instytut Duszpasterstwa Emigracyjnego im. Kard. Augusta Hlonda w Poznaniu", http://www.emigracja.chrystusowcy.pl/index.php/dzie-migranta [dostęp: 28.12.2016].

Tomasik K., Arcybiskup Bambergu o uchodźcach, ŚDM i relacjach polsko-niemieckich [wywiad z abp Ludwikiem Schickiem], „Portal E-Kai”, https://ekai.pl/wydarzenia/temat_dnia/x100484/ arcybiskup-bambergu-o-uchodzcach-sdm-i-relacjach-polsko-niemieckich/. 08.06.2016 [dostęp: 05.06.2016].

Ukraińcy pracujacy w Polsce będa mieli swój zwiazek zawodowy? Powoła go OPZZ, „Portal Biznes.Onet.pl”, http://biznes.onet.pl/praca/zwiazek-zawodowy-pracownikow-ukrainskich-wpolsce-pomysl-opzz/jjpqrx [dostęp: 27.05.2016].

Urząd do Spraw Cudzoziemców, Podsumowanie roku [2016] ustawy o cudzoziemcach, s. 4-5, http:// udsc.gov.pl/statystyki/raporty-specjalne/podsumowanie-roku-ustawy-o-cudzoziemcach/ [dostęp: 02.01.2017].

Warum nun auch Kardinal Marx eine Begrenzung der Migration fordert, Bonn. 07.02.2016, „Portal CNA. Deutsche Ausgabe", http://de.catholicnewsagency.com/story/kardina-marx-fordert-nunbegrenzung-der-migration-0468 [dostęp: 11.06.2016].

Wilczak J., Niewidzialni. Milion Ukrainców w Polsce: Kim sq? Gdzie pracuja?, „Portal Polityka”. 14.06.2016, http://www.polityka.p1/tygodnikpolityka/spoleczenstwo/1664626,1,milionukraincow-w-polsce-kim-sa-gdzie-pracuja.read [dostęp: 27.12.2016].

Woellert F., Kröhnert S., Sippel L., Klingholz R., Ungenutzte Potenziale. Zur Lage der Integration in Deutschland, Berlin 2009, s. 12-27, „Portal Berlin-Institut für Bevölkerung und Entwicklung", http://www.berlin-institut.org/fileadmin/user_upload/Zuwanderung/Integration_RZ_online.pdf [dostęp: 29.12.2016].

Zawadka G., Ukraińcy chca pracować w Polsce i ratuja polska gospodarke, „Portal RP.pl” [Rzeczpospolita] 27.10.2016, http://www.rp.pl/Dane-gospodarcze/310279833-Ukraincy-chca-praco wac-w-Polsce-i-ratuja-polska-gospodarke.html\#ap-1 [dostęp: 27.12.2016].

Zuchowicz K., Polska przyjęła już ponad 80 tysięcy Czeczenów i wciąż przyjmuje następnych. Czy komuś to przeszkadza?, „Portal dyskusyjny: Na:Temat”, http://natemat.p1/155107,polskaprzyjela-juz-blisko-90-tysiecy-uchodzcow-z-czeczenii-dzis-zostala-ich-tylko-garstka-bo-niechcieli-u-nas-zostac [dostęp: 29.12.2016].

Biskup Józef Wróbel SCJ, dr hab. prof. KUL, kierownik Katedry Bioetyki Teologicznej KUL, członek Komisji Bioetycznej przy Konferencji Episkopatu 
Polski, członek towarzystw naukowych oraz rad naukowych periodyków naukowych; autor książek i licznych artykułów, specjalizuje się w problematyce bioetycznej i teologicznomoralnej. 